\title{
Pox-Pirometallurgical Processing Method for Gold-Bearing and Lead-Zinc Concentrates
}

\author{
Ivan I. Evtushevich ${ }^{\mathrm{a}^{*}}$, Chermen T. Dzgoev ${ }^{\mathrm{a}}$, \\ Alexander V. Epiforov ${ }^{b}$, Sergey S. Gudkov ${ }^{b}$, \\ Yuriy Ye. Emelianov ${ }^{b}$ and Stanislav V. Balikov ${ }^{b}$ \\ ${ }^{a}$ Novoangarsky Dressing Plant LLC \\ 19 Prosveshcheniya Str., Novoangarsk village, 663412, Russia \\ ${ }^{b}$ Irkutsk Research Institute of Precious and Rare Metals \\ and Diamonds IRGIREDMET JSC \\ 38 Gagarina Str., Irkutsk, 664025, Russia
}

Received 28.02.2017, received in revised form 15.03.2017, accepted 23.03.2017

Developed and tested in the pilot mode technology for processing sulfide gold-bearing concentrates containing carbonates, preg-robbing carbonaceous matter, arsenic, antimony and sulfur and lead concentrates containing zinc and silver. This technology includes pressure oxidation of this concentrates for extraction of sulfur, arsenic and zinc to the solution and reduction smelting of the POX cakes for obtaining refined lead and precious metals alloy. The developed technology promotes to recover $97 \%$ precious metals and $95 \%$ zinc and lead in commercial products and eliminates of POX cakes cyanidation.

Keywords: refractory gold-sulfide concentrates, polymetallic concentrates, pressure oxidation, reduction smelting, primary lead, precious metals.

DOI: $10.17516 / 1998-2836-0011$.

(c) Siberian Federal University. All rights reserved

* Corresponding author E-mail address: evtushevich59@mail.ru 


\title{
Автоклавно-пирометаллургический способ переработки золотосодержащих \\ и свинцово-цинковых концентратов
}

\author{
И.И. Евтушевич ${ }^{\text {, }}$ Ч.Т. Дзгоев ${ }^{\text {a }}$, А.В. Епифоров ${ }^{0}$, \\ С.С. Гудков ${ }^{\sigma}$, Ю.Е. Емельянов ${ }^{0}$, С.В. Баликов ${ }^{\sigma}$ \\ ${ }^{a} О О О$ «Новоангарский обогатительный комбинат» \\ Россия, 663412, пос. Новоангарск, ул. Просвещуения, 19 \\ ${ }^{6}$ Иркутский научно-исследовательский институт благородных \\ и редких металлов и алмазов АО «Иргиредмет» \\ Россия, 664025, Иркутск, ул. Гагарина, 38
}

Разработана и испытана в полупромышленном масштабе технология переработки золотосульфидных концентратов, содержащих карбонаты, органический сорбчионноактивный углерод, мышьяк, сурьму и серу, и свинцовых концентратов, содержащих иинк и серебро. Технология включает автоклавное окисление данных концентратов для извлечения в раствор серы, мышьяка и циинка и восстановительную плавку кеков автоклавного окисления для получения марочного свиниа и драгоценных металлов. Разработанная технология позволяет извлекать $97 \%$ драгоиенных металлов и $95 \%$ иинка и свиниа в товарные продукты и отказаться от цианирования кеков автоклавного окисления.

Ключевые слова: упорные золотосульфидные концентраты, полиметаллические концентраты, автоклавное окисление, восстановительная плавка, черновой свинеи, драгоиенные металлы.

\section{Введение}

Более 80 \% золотосодержащих руд в мире перерабатывается методом цианирования, однако существует особый вид «упорных» руд, извлечение драгоценных металлов из которых цианированием осложнено. Наиболее распространенным типом золотосодержащих упорных руд являются сульфидные руды, которые также могут иметь «двойную упорность» и содержать органический сорбционноактивный углерод и/или химические депрессоры золота - цианисиды. Типовые схемы переработки упорных руд включают в себя флотационное обогащение с выделением отвальных хвостов и цианирования концентратов после предварительного вскрытия золота в сульфидах [1].

Наиболее изученным и широко распространенным в промышленности считается окислительный обжиг, который во многих случаях является весьма эффективным методом для переработки золотосульфидных концентратов. Сдерживающим фактором применения обжига выступали экологические соображения и необходимость создания сложных систем пыле- и газоочистки. На различных обжиговых предприятиях из газовой фазы получают триоксид мышьяка и диоксид серы для производства серной кислоты [2].

Гидрометаллургические способы переработки упорных золотосульфидных концентратов более экологичны. Использование бактериального, или «атмосферного», окисления $[3,4]$ в 
ряде случаев позволяет добиться приемлемых показателей по извлечению золота. Однако есть факторы, которые тормозят широкое распространение данных технологий: значительная продолжительность процесса окисления (до нескольких суток); образование элементарной серы при окислении сульфидных минералоав, которая препятствует доступу цианида к поверхности золота и значительно увеличивает его расход; необходимость сверхтонкого измельчения окисляемого концентрата до Р95 10-40 мкм; высокая «чувствительность» к изменению состава сырья, подаваемого на окисление; низкая эффективность применительно к золотопиритным концентратам и др.

Наиболее универсальным гидрометаллургическим способом переработки сульфидных золотосодержащих руд и концентратов является автоклавное окисление (AО) [5], которое позволяет быстро и эффективно окислить все сульфидные минералы и серу до сульфатов металлов, что исключает вредные выбросы в атмосферу и дает возможность извлекать цианированием до 99 \% золота [6,7]. Однако в случае переработки концентратов, содержащих органический сорбционноактивный углерод, цианирование кеков АО малоэффективно ввиду автоклавного «прег-роббинга» золота [8]. Кроме того, процесс АО не позволяет вскрывать золото, тонковкрапленное в кварце и других нерастворимых в серной кислоте минералах, которое тоже теряется с хвостами цианирования. Извлечение серебра из кеков АО цианированием характеризуется низкими показателями, так как серебро при АО приобретает вторичную упорность - переходит в аргентоярозит [9]. Металлы-цианисиды (медь, цинк и др.) переходят в раствор АО и могут извлекаться в товарные продукты в отдельном цикле.

При переработке полиметаллических сульфидных концентратов одним из наиболее эффективных способов, как и в случае с золотосульфидными концентратами, признан процесс высокотемпературного АО при температурах $200-220^{\circ} \mathrm{C}$, позволяющий извлекать максимальное количество цветных металлов в сернокислый раствор и окислять всю серу до сульфатиона, а мышьяк до мышьяковой кислоты и арсенатов при этом свинец и драгоценные металлы остаются в кеках АО [10]. Наличие в кеках автоклавного окисления свинца способствует извлечению драгоценных металлов при восстановительной плавке кеков с последующим рафинированием чернового свинца.

Целью исследования стала разработка технологии, включающей процессы автоклавного окисления и восстановительной плавки кеков АО для совместной переработки золотосульфидных концентратов, содержащих карбонаты, органический сорбционноактивный углерод, мышьяк, сурьму и серу, и свинцовых концентратов, содержащих цинк и серебро. Комбинированная автоклавно-пирометаллургическая технология позволит перерабатывать широкий спектр сульфидного сырья и является более универсальной по отношению к золото- и серебросодержащему сырью, чем традиционная автоклавно-цианистая технология, так как дает возможность отказаться от цианирования кеков автоклавного окисления.

\section{Лабораторные исследования}

Объекты исследований - золотосульфидный флотоконцентрат месторождения «Удерейское» (Au-S) и свинцово-цинковый флотоконцентрат месторождения «Горевское» (полупродукт свинцовый - ППС). Массовая доля серы в ППС составляет 19 \%. При этом практически 
Таблица 1. Основные компоненты флотоконцентратов

\begin{tabular}{|c|c|c|c|c|c|}
\hline \multirow{2}{*}{ Компонент } & \multicolumn{2}{|c|}{ Массовая доля, \% } & \multirow{2}{*}{ Компонент } & \multicolumn{2}{|c|}{ Массовая доля, \% } \\
\hline & ППС & $\mathrm{Au}-\mathrm{S}$ & & ППС & $\mathrm{Au}-\mathrm{S}$ \\
\hline $\mathrm{SiO}_{2}$ & 7,1 & 13,5 & $\mathrm{~Pb}_{\mathrm{Ol}}$ & 7,9 & - \\
\hline $\mathrm{Al}_{2} \mathrm{O}_{3}$ & 0,1 & 1,1 & $\mathrm{~Pb}_{\mathrm{cy}}$ & 25,3 & - \\
\hline $\mathrm{CaO}$ & 1,0 & 0,06 & $\mathrm{Zn}_{\text {окисл }}$ & 0,3 & - \\
\hline $\mathrm{K}_{2} \mathrm{O}$ & 0,05 & 0,2 & $\mathrm{Zn}_{\text {cysh } \phi}$ & 17,9 & - \\
\hline $\mathrm{Na}_{2} \mathrm{O}$ & $<0,02$ & 0,2 & $\mathrm{As}_{\text {окисл }}$ & $<0,02$ & 0,1 \\
\hline $\mathrm{Fe}_{\text {окисл }}$ & 10,1 & 0,6 & $\mathrm{As}_{\text {сульф }}$ & 0,1 & 6,7 \\
\hline $\mathrm{Fe}_{\text {сульф }}$ & 2,2 & 33,2 & $\mathrm{Sb}_{\text {окисл }}$ & 0,03 & 1,7 \\
\hline $\mathrm{S}_{\text {окисл. }}$ & 0,6 & $<0,2$ & $\mathrm{Sb}_{\mathrm{cy}}$ & 0,07 & 3,7 \\
\hline $\mathrm{S}_{\text {сульф }}$ & 18,4 & 36,7 & $\mathrm{Cu}_{\text {обш }}$ & 0,06 & 0,02 \\
\hline $\mathrm{Au}, \Gamma / \mathrm{T}$ & 0,04 & 22,0 & $\mathrm{Ag}, \Gamma / \mathrm{T}$ & 235,0 & 9,0 \\
\hline
\end{tabular}

вся сера находится в сульфидной форме и связана с цинком и свинцом. Литофильные компоненты представлены в основном оксидом кремния.

В золотосульфидном флотоконцентрате основными компонентами выступают сера и железо. Их массовая доля составляет 36,7 и 33,8 \% соответственно. На долю мышьяка приходится 6,8 , сурьмы - 5,4 \%. Рациональным анализом на золото установлена упорность золотосульфидного концентрата к цианистому процессу. В цианируемой форме находится $9 \%$ золота, с сульфидами ассоциировано 50 \% металла. Кроме того, концентрат является сорбционноактивным, так как содержит органический углерод, извлечение золота из кеков автоклавного окисления не превышает $87 \%$ [11].

Промышленную ценность в ППС представляют свинец, цинк и серебро. В золотосульфидном - золото. Сурьма является попутно извлекаемым компонентом. Содержание основных компонентов во флотоконцентрах представлено в табл. 1.

Золотосульфидный концентрат содержит 80,4 \% сульфидов: пирит (60,7 \%), арсенопирит $(14,5 \%)$ и антимонит $(5,2 \%)$ (рис. $1 a)$. Концентрат содержит $12 \%$ кварца и $6,5 \%$ алюмосиликатов. В концентрате ППС сульфидные минералы представлены в основном сфалеритом и галенитом, в меньшей степени - пирротином, пиритом, марказитом. Из карбонатов преобладает сидерит - $11 \%$

Перед совместной восстановительной плавкой исследуемых концентратов на черновой свинец проводили предварительное автоклавное окисление для извлечения серы, мышьяка и цинка в раствор. Автоклавное окисление осуществляли как по отдельности, так и на смеси концентратов.

Исследовано влияние продолжительности автоклавного окисления концентрата $\mathrm{Au}-\mathrm{S}$ от температуры, парциального давления кислорода и крупности измельчения (рис. 1) [12].

Установлено, что оптимальными условиями $\mathrm{AO}$ Au-S являются: температура $220{ }^{\circ} \mathrm{C}$, парциальное давление кислорода 3,0 МПа; крупность материала, поступающего на окисление, не должна превышать 40 мкм. При данных условиях степень окисления сульфидов составляет 

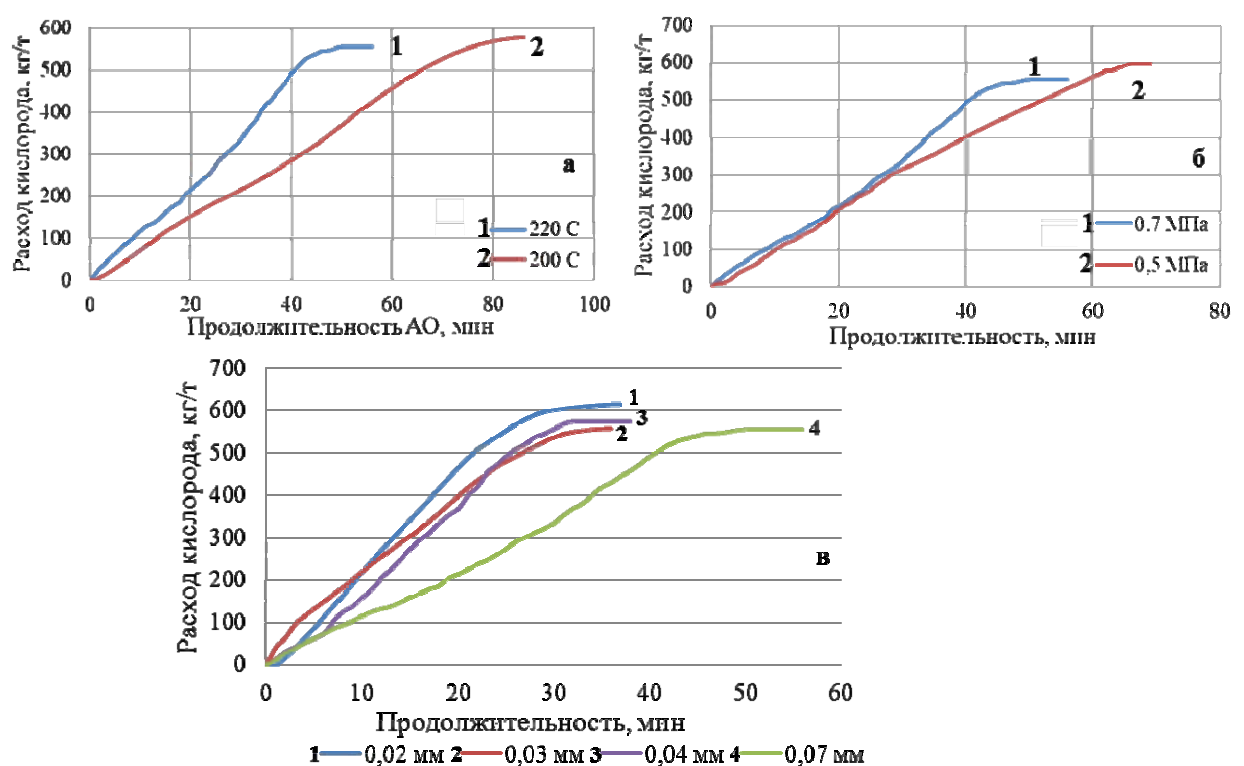

Рис. 1. Зависимость продолжительности автоклавного окисления Au-S от температуры (а) парциального давления кислорода (б) и крупности измельчения (в)
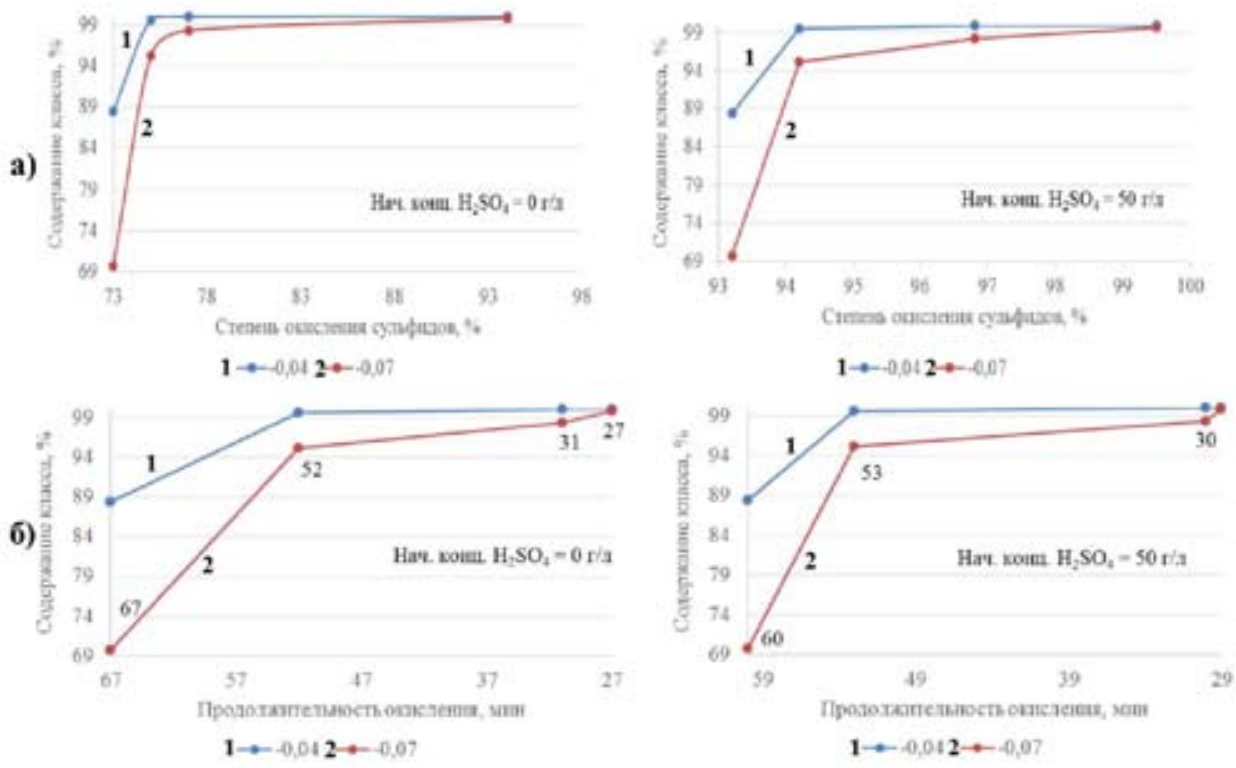

Рис. 2. Зависимость степени окисления сульфидов (а) и продолжительности АО (б) от крупности ППС и начальной кислотности

более $99 \%$, продолжительность АО - 38-40 мин, извлечение серы и мышьяка в раствор - 95-98 и $80-86 \%$ соответственно.

В связи с высоким содержанием карбонатов в свинцово-цинковом концентрате проведена предварительная кислотная обработка. Автоклавное окисление осуществляли при начальной 
загрузке серной кислоты 0 и 50 г/л, крупности материала 98 \% класса минус 40 и минус 70 мкм, температуре $220^{\circ} \mathrm{C}$ и давлении 3,0 МПа (рис. 2).

Установлено, что для окисления сульфидной серы на 94-99 \% и для извлечения цинка в раствор не менее 99 \% крупность материала должна составлять не менее $96 \%$ класса минус 40 мкм. При этом начальная концентрация кислоты равна 50 г/л.

Проведены исследования по автоклавному окислению смеси золотосульфидного и свинцово-цинкового флотоконцентрата в различном соотношении. Показано, что при АО цинк извлекается в раствор более чем на 99 \%. Выход кека АО начинает снижаться при соотношении ППС : Au-S $\leq 2: 1$. Извлечение серы, мышьяка и железа в раствор увеличивается при снижении содержания свинца в исходной смеси. Соотношение концентратов в смеси не влияет на степень окисления сульфидов и извлечение цинка в раствор. Увеличение содержания $\mathrm{Au}-\mathrm{S}$ в смеси приводит к снижению выхода кека, увеличению извлечения железа, мышьяка и серы в раствор. На рис. 3 представлены зависимости продолжительности процесса $\mathrm{AO}$ и расхода кислорода от соотношения ППС:Au-S.

Установлено, что при увеличении соотношения ППС:Au-S продолжительность АО увеличивается, а расход кислорода снижается. При этом минимальная продолжительность процесса (45-47 мин) при расходе кислорода 510-515 кг/т достигается при соотношении ППС:Au-S=1:1, которое является оптимальным. Выход кека АО составил 50 \% и извлечении серы и мышьяка в раствор 73 и $42 \%$ соответственно. При этом в кеках АО содержится 1,4 \% мышьяка и 7,4 \% серы. Массовая доля свинца составляет $24 \%$.

Исследование кека АО золотосульфидного концентрата показало, что кек АО содержит 10,7 \% серы и 3,9 \% мышьяка. Содержание железа составляет 15,5 \%. Сурьма также остается в кеке, массовая доля $2,9 \%$.

Для удаления гидратированных форм серы и железа в раствор провели кондиционирование пульпы АО при температуре $95^{\circ} \mathrm{C}$ (Hot Cure process) [13]. Кек после кондиционирования окисленной пульпы содержит, \%: 0,2 S, 3,8 Fe, 1,5 As и 3,9 Sb. Полученные данные свидетельствуют о том, что при кондиционировании пульпы происходит растворение гидратированных сульфатных соединений железа и мышьяка, что значительно сокращает массу осадка и приво-

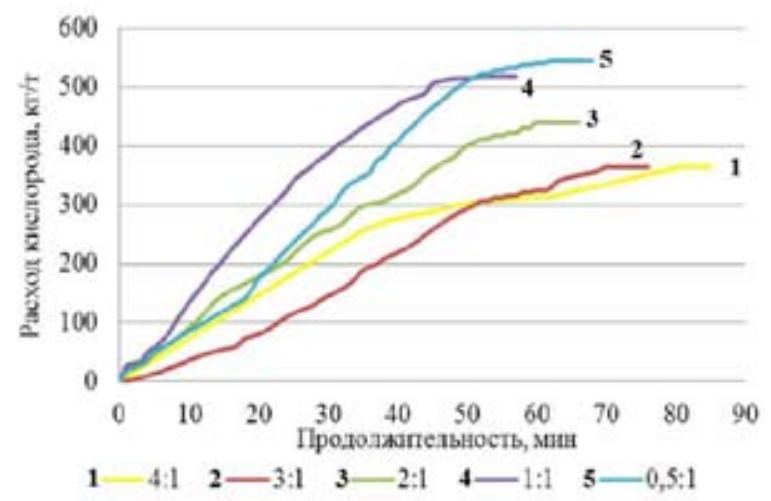

Рис. 3. Зависимость продолжительности и расхода кислорода при АО смесей от соотношения ППС: $\mathrm{Au}-\mathrm{S}$ 

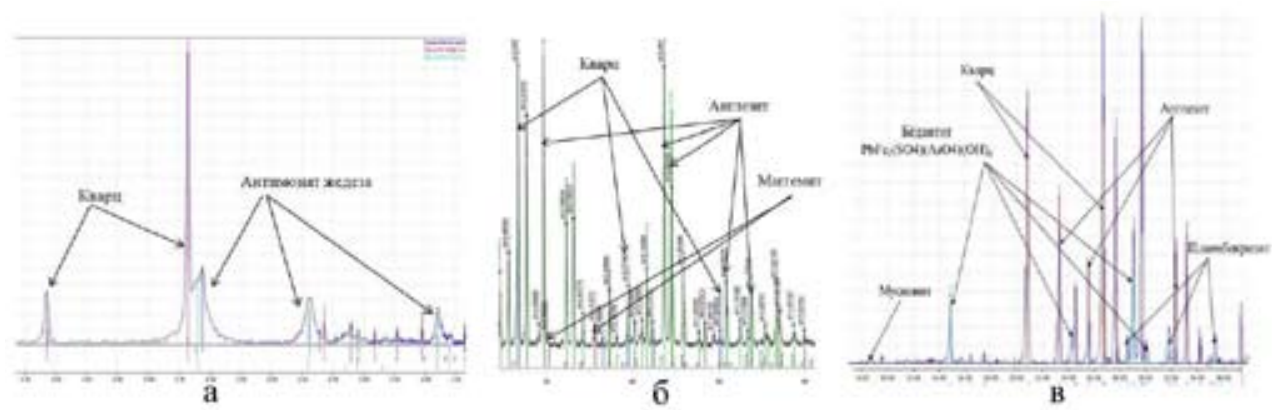

Рис. 4. Фрагменты дифрактограмм: a - кек AO Au-S; б - кек AO ППС; в - кек AO смеси Au-S и ППС (1:1)

дит к его обогащению по золоту, серебру и свинцу. Кек состоит из кварца и антимоната железа (рис. $4 a$ ).

Установлено, что кек АО ППС на 65,8 \% состоит из англезита. Прочими компонентами являются оксиды железа и кварц (рис. 4б). Полученный кек имеет достаточно высокое содержание серы $(8,5$ \%), связанной со свинцом, поэтому возникает необходимость в ее удалении перед ВП.

Кек $\mathrm{AO}$ смеси $\mathrm{Au}-\mathrm{S}$ и ППС в соотношении 1:1 состоит из бедантита, плюмбоярозита и англезита (рис. 4в). Также кек содержит кварц, оксид железа и мусковит. Кек имеет высокое содержание мышьяка $(1,5 \%)$ и серы (5,6 \%), поэтому перед восстановительной плавкой необходимо их удаление.

Проведены исследования процесса восстановительной плавки кеков автоклавного окисления золотосульфидного (Au-S) и свинцово-цинкового (ППС) концентратов и их смеси в соотношении 1:1.

Для удаления остаточного содержания серы и мышьяка в кеках автоклавного окисления проведена щелочная обработка (ЩО) кеков. Растворение серы и мышьяка протекает по следующим реакциям:

$$
\begin{aligned}
& \mathrm{PbSO}_{4}+2 \mathrm{NaOH} \rightarrow \mathrm{Na}_{2} \mathrm{SO}_{4}+\mathrm{Pb}(\mathrm{OH})_{2}, \\
& \mathrm{~Pb}_{0,5} \mathrm{Fe}_{3}\left(\mathrm{SO}_{4}\right)_{2}(\mathrm{OH})_{6}+4 \mathrm{NaOH} \rightarrow 0,5 \mathrm{~Pb}(\mathrm{OH})_{2}+3 \mathrm{Fe}(\mathrm{OH})_{3}+2 \mathrm{Na}_{2} \mathrm{SO}_{4}, \\
& \mathrm{PbFe}_{3}\left(\mathrm{AsO}_{4}\right)\left(\mathrm{SO}_{4}\right)(\mathrm{OH})_{6}+5 \mathrm{NaOH} \rightarrow \mathrm{Pb}(\mathrm{OH})_{2}+3 \mathrm{Fe}(\mathrm{OH})_{3}+\mathrm{Na}_{2} \mathrm{SO}_{4}+\mathrm{Na}_{3} \mathrm{AsO}_{4}, \\
& \mathrm{FeAsO}_{4}+3 \mathrm{NaOH} \rightarrow \mathrm{Na}_{3} \mathrm{AsO}_{4}+\mathrm{Fe}(\mathrm{OH})_{3} .
\end{aligned}
$$

Химический состав кеков после ЩО представлен в табл. 2.

Рентгеноструктурный анализ показал, что кеки ЩО состоят из оксидов кремния и свинца. Железо в кеках присутствует в форме рентгеноаморфных соединений и антимоната (рис. 5).

Таким образом, основными соединениями, поступающими на восстановительную плавку (ВП), являются: гидратированные оксиды свинца (глет, массикот) и железа (гематит-магнетит, гетит), диоксид кремния, оксид алюминия, арсенаты и антимонаты железа (пятиокись мышьяка и сурьмы), а также небольшое количество серосодержащих соединений - сульфидов и суль- 
Таблица 2. Химический состав кеков ЩО

\begin{tabular}{|c|c|c|c|}
\hline \multirow{2}{*}{ Компонент } & \multicolumn{3}{|c|}{ Массовая доля в продукте ЩО, \% } \\
\cline { 2 - 4 } & ППС & Au-S & Смесь \\
\hline $\mathrm{SiO}_{2}$ & 12,8 & 32,1 & 1,8 \\
\hline $\mathrm{Al}_{2} \mathrm{O}_{3}$ & 0,9 & 1,8 & 0,5 \\
\hline $\mathrm{CaO}$ & 1,3 & 0,1 & 1,1 \\
\hline $\mathrm{S}$ & 1,5 & 0,1 & 16,7 \\
\hline $\mathrm{Fe}$ & 16,7 & 5,2 & 0,1 \\
\hline $\mathrm{Zn}$ & 0,1 & - & 0,6 \\
\hline $\mathrm{As}$ & 0,1 & 1,3 & 2,0 \\
\hline $\mathrm{Sb}$ & 0,2 & 1,4 & 33,3 \\
\hline $\mathrm{Pb}$ & 57,5 & - & 29,9 \\
\hline $\mathrm{Au}, \Gamma / \mathrm{T}$ & 0,08 & 93,7 & 351,3 \\
\hline $\mathrm{Ag}, \Gamma / \mathrm{r}$ & 536 & 36,7 & \\
\hline
\end{tabular}

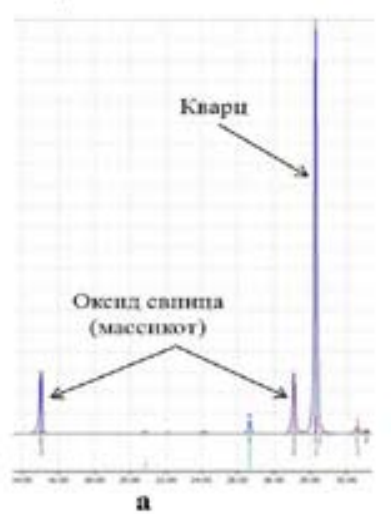

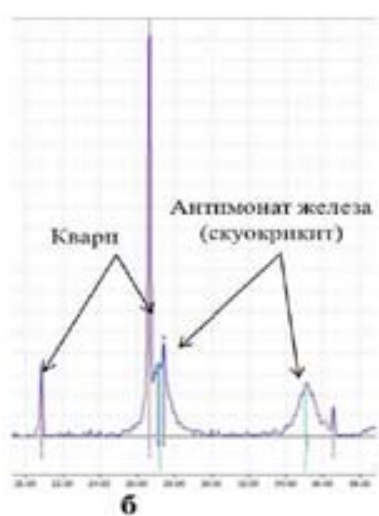

6

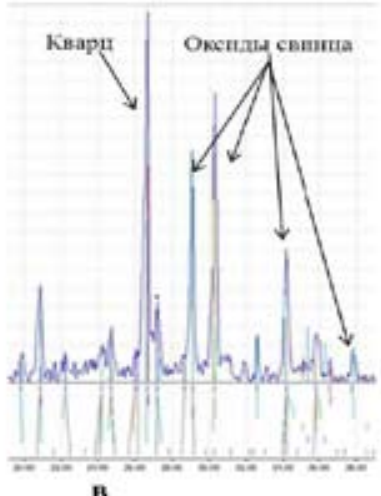

Рис. 5. Фрагменты дифрактограмм кеков ЩО: a - ППС; б - Au-S; в - смесь

фатов. Исследования по восстановительной плавке проведены в лабораторной шахтной печи в шамотовых тиглях объемом 0,7 л при температуре $1200{ }^{\circ} \mathrm{C}$. В качестве флюсов использовали известь, кварцевый песок, кальцинированную соду, оксид железа, металлическое железо. Восстановитель - кокс.

Тигель с шихтой при помощи щипцов помещали в предварительно разогретую до рабочей температуры печь, выдерживали необходимое время, по прошествии которого тигель с расплавом вынимали из печи, остужали и разбивали для извлечения веркблея и шлака.

Содержание свинца в черновом металле составило 89-93 \%, основной примесью является сурьма (табл. 3).

Лабораторными исследованиями показано, что сочетание процессов автоклавного окисления золотосульфидного и свинцово-цинкового флотоконцентратов с последующей восстановительной плавкой кеков позволяет извлекать в черновой металл до 98 \% свинца и 
Таблица 3. Химический состав слитков чернового свинца

\begin{tabular}{|c|c|c|c|c|c|c|c|c|c|c|c|}
\hline \multirow{2}{*}{ Продукт ЩО } & \multicolumn{9}{|c|}{ Массовая доля, \% } & \multicolumn{2}{|c|}{ Содержание, г/т } \\
\hline & $\mathrm{Pb}$ & $\mathrm{Zn}$ & As & $\mathrm{Ca}$ & $\mathrm{Cu}$ & $\mathrm{Fe}$ & $\mathrm{Mg}$ & $\mathrm{S}$ & $\mathrm{Sb}$ & $\mathrm{Au}$ & $\mathrm{Ag}$ \\
\hline Смесь & 92,9 & 0,02 & 0,34 & 0,07 & 1,1 & 1,6 & 0,005 & 0,03 & 5,5 & 83,0 & 972 \\
\hline ППС+Au-S (1:1) & 89,5 & 0,02 & 0,79 & 0,06 & 1,5 & 3,1 & 0,006 & 0,07 & 6,3 & 130 & 842 \\
\hline ППС & 98,7 & 0,03 & 0,34 & 0,11 & 0,2 & 0,3 & 0,01 & 0,02 & 0,4 & 0,15 & 924 \\
\hline
\end{tabular}

98-99 \% золота и серебра. Предложенная технология была испытана в полупромышленном масштабе.

\section{Полупромышленные испытания}

Полупромышленные испытания автоклавно-пирометаллургической технологии проведены на смесях золотосульфидных флотоконцентратов Удерейского, Боголюбовского и Олимпиадинского месторождений со свинцово-цинковым флотоконцентратом (ППС) месторождения «Горевское» (табл. 4).

Схема полупромышленных испытаний автоклавно-пирометаллургической технологии представлена на рис. 6 .

Испытания по автоклавному окислению проведены в непрерывном режиме на автоклавной пилотной установке (АПУ), включающей: расходные баки с мешалками, насос высокого давления для подачи пульпы в автоклав, четырехсекционный автоклав общей рабочей вместимостью 35,5 дм³ (рис. 7), емкости разгрузки пульпы, емкости для сброса абгаза, реакторы с подогревом для кондиционирования окисленной пульпы.

В процессе полупромышленных испытаний (ППС) получено 50 кг кека автоклавного окисления смеси золотосульфидных флотоконцентратов, 23 кг кека АО ППС и 57 кг кека АО смеси золотосульфидных и свинцово-цинкового концентратов. Извлечение серы и мышьяка из смеси

Таблица 4. Химический состав флотоконцентратов

\begin{tabular}{|c|c|c|c|c|c|}
\hline \multirow{2}{*}{ Компонент } & \multirow{2}{*}{ ППС } & \multicolumn{4}{|c|}{ Золотосульфидные } \\
\cline { 3 - 5 } & & \multirow{2}{*}{ Удерейский } & \multicolumn{2}{|c|}{ Олимпиадинский } & Боголюбовский \\
\cline { 3 - 5 } & 10,1 & 33,8 & 19 & 19,6 & 26 \\
\hline $\mathrm{Fe}_{\text {общ }}$ & 19,6 & 36,7 & 19,3 & 14,9 & 25,1 \\
\hline $\mathrm{S}_{\text {общ }}$ & 19 & 36,7 & 19,2 & 14,8 & 25,1 \\
\hline $\mathrm{S}_{\text {сульф }}$ & 32 & 0,4 & 0,02 & 0,02 & 0,02 \\
\hline $\mathrm{Pb}_{\text {общ }}$ & 18,5 & 0,1 & 0,05 & 0,03 & 0,02 \\
\hline $\mathrm{Zn}_{\text {общ }}$ & 0,1 & 6,8 & 5,4 & 4,2 & 2,5 \\
\hline $\mathrm{As}_{\text {общ }}$ & 0,1 & 5,4 & 5,8 & 3,7 & 0,05 \\
\hline $\mathrm{Sb}_{\text {общ }}$ & $<0,1$ & 22 & 62,7 & 35,3 & 18,1 \\
\hline $\mathrm{Au}, \Gamma / \mathrm{T}$ & 265 & 9 & $<0,1$ & $<0,1$ & 4,1 \\
\hline $\mathrm{Ag}, \Gamma / \mathrm{T}$ & & & \\
\hline
\end{tabular}




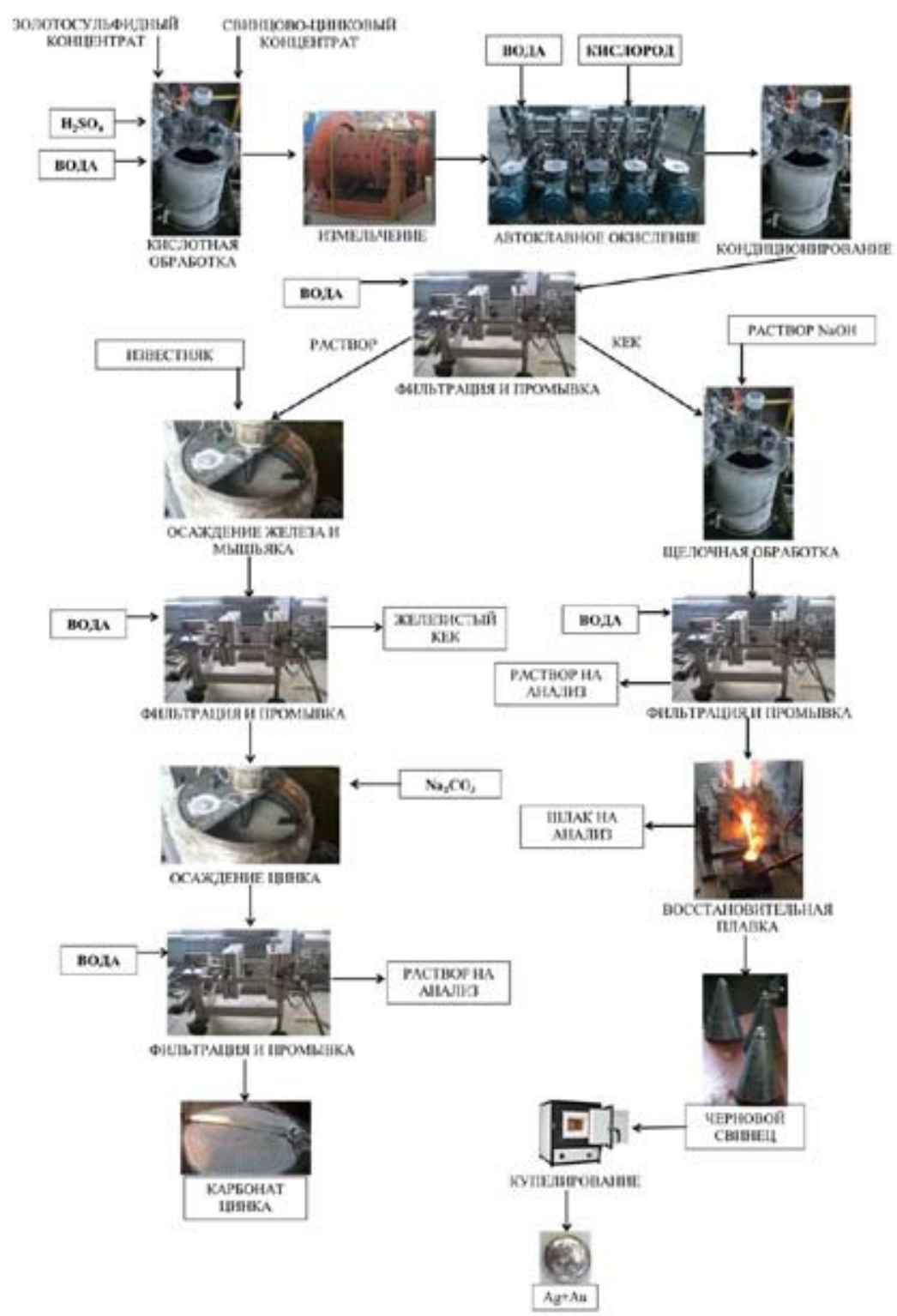

Рис. 6. Схема полупромышленных испытаний

золотосульфидных концентратов в раствор составило 98 и 87 \%, из смеси золотосульфидных и свинцово-цинкового концентратов - 98 и 77 \% соответственно. Извлечение серы в раствор из свинцово-цинкового концентрата составило 93 \%. Извлечение цинка составило 99 \%. При осаждении цинка из растворов кальцинированной содой получен карбонатный цинковый концентрат (рис. 8) с содержанием цинка 57,3 \%.

Восстановительную плавку кеков АО проводили в двухэлектродной руднотермической электропечи марки «3-3М» рабочим объемом 9 дм³ с графитовыми электродами. Восстановительную плавку осуществляли в накопительном режиме, шихту подавали порциями по 100-150 г на поверхность расплава. Интенсивность загрузки зависела от 

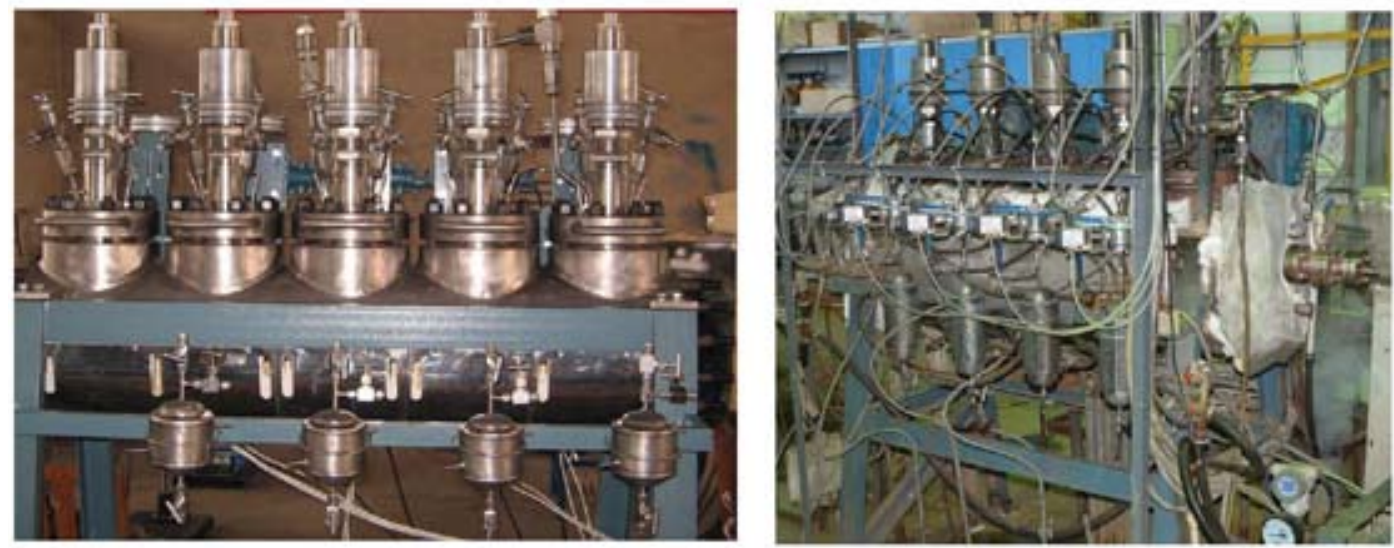

Рис. 7. Горизонтальный автоклав для пилотных испытаний

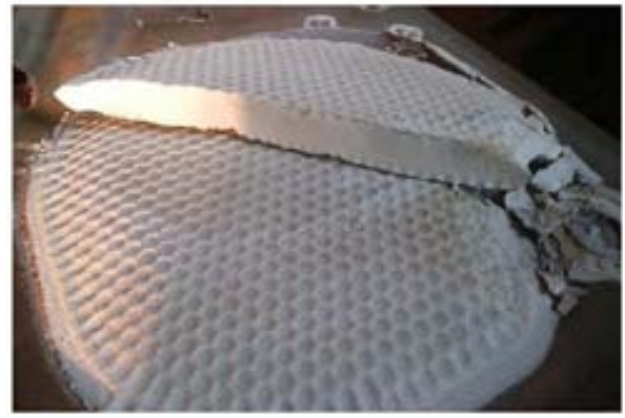

Рис. 8. Карбонатный цинковый концентрат. Кек фильтрации

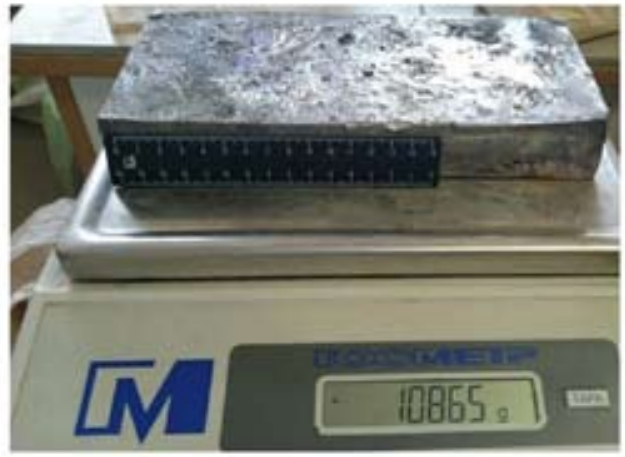

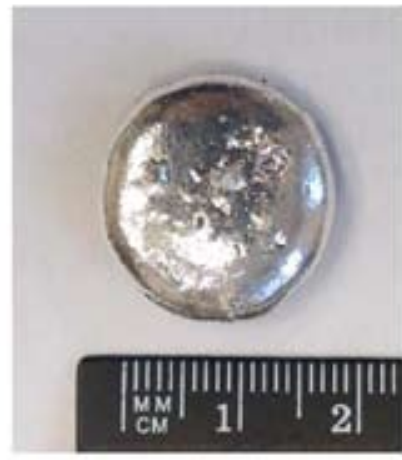

6

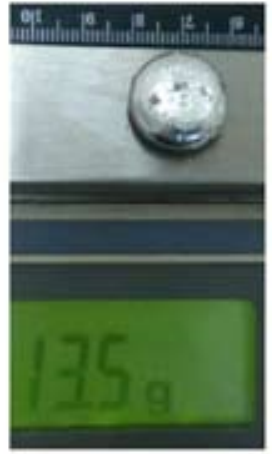

Рис. 9. Слиток чернового свинца (а); серебряно-золотой слиток (б)

скорости расплавления шихты и в среднем составляла раз в 5-7 мин. Слив шлака проводили по мере его накопления. Металл сливали в конце опыта после удаления избытков шлака. Слив металла и шлака производили спустя 60 мин после расплавления последней порции материала. 
При восстановительной плавке кеков АО получен черновой свинец (рис. 9a), извлечение свинца, золота и серебра в черновой металл составило 95, 97 и 96 \% соответственно. Извлечение сурьмы - 73-81 \%. В результате переработки чернового свинца, включающей щелочное рафинирование от сурьмы и мышьяка и извлечение драгоценных металлов, получен серебряно-золотой слиток массой 13,5 г с содержанием золота 8,33 \% и серебра 91,62\% (рис. 9б).

\section{Результаты исследований}

По результатам лабораторных [14] и полупромышленных испытаний разработана технологическая схема (рис. 10) [15-17], позволяющая извлекать до 97 \% драгоценных металлов и до 95 \% цинка и свинца в товарные продукты. Разработанная технология позволяет отказаться от цианирования кеков автоклавного окисления.

Схема включает последовательность операций: доизмельчение свинец- и золотосодержащих концентратов; кислотная обработка доизмельченных концентратов; автоклавное окисление смеси концентратов и кондиционирование окисленной пульпы; щелочная обработка кеков $\mathrm{AO}$; плавка кеков ЩО на черновой свинец; переработка чернового свинца с получением мароч-

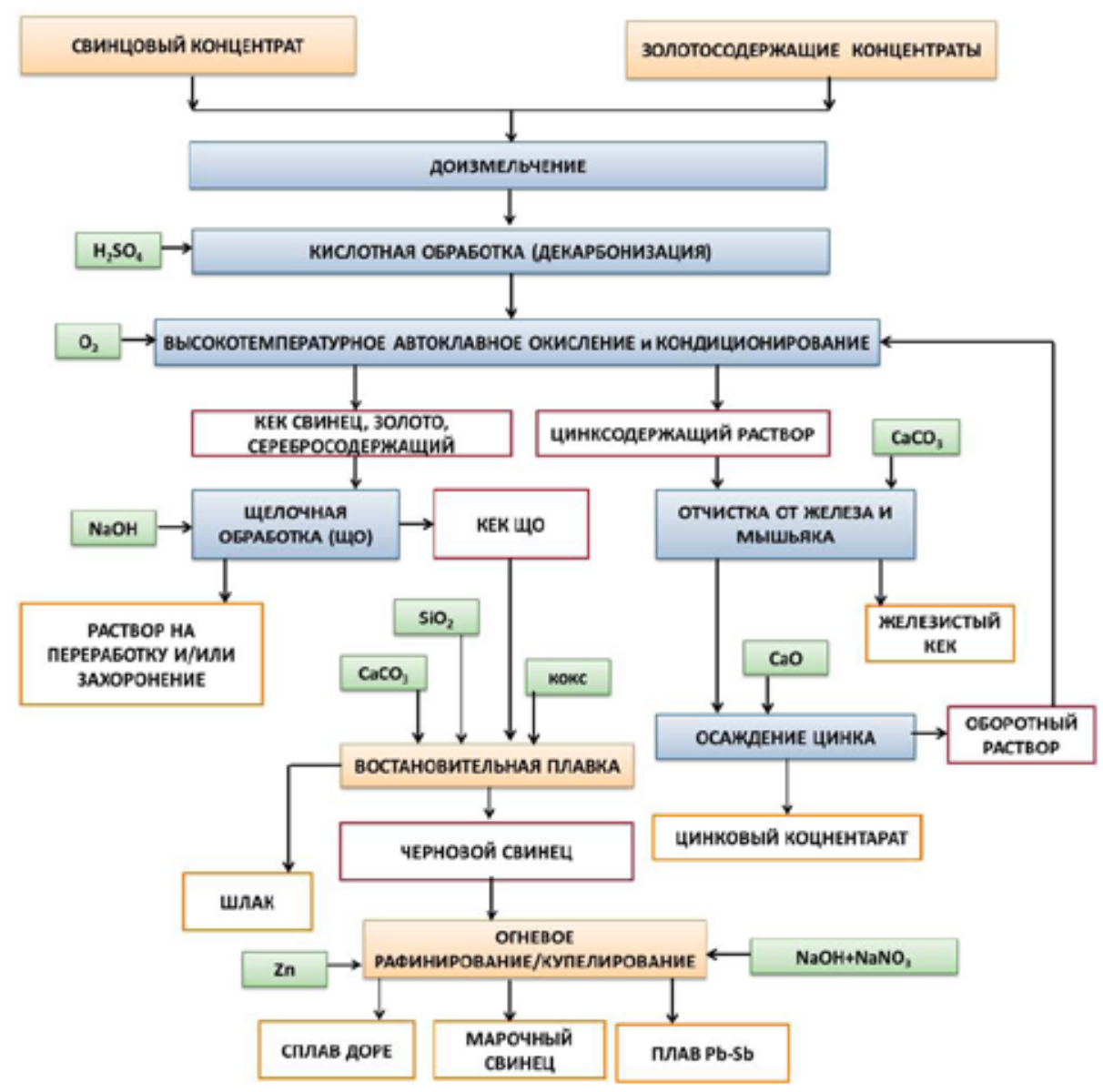

Рис. 10. Технологическая схема переработки золотосульфидных и свинцово-цинковых концентратов 
ного свинца и сплава Доре; очистка раствора АО от мышьяка и железа известняком; осаждение цинка из раствора АО известью.

\section{Выводы}

Исследованиями по оптимизации автоклавного окисления золотосульфидного и свинцовоцинкового концентратов показано, что оптимальной температурой АО для исследуемых концентратов является $220^{\circ} \mathrm{C}$ при парциальном давлении кислорода 0,7 МПа. Оптимальная крупность измельчения исследуемых концентратов составляет 96-98 \% - 40 мкм.

Кондиционирование окисленной пульпы сокращает выход автоклавного остатка.

При переработке свинцово-цинкового концентрата необходима предварительная кислотная обработка для разрушения карбонатов. Начальная кислотность пульпы, поступающей на АО, должна составлять 50 г/л.

При переработке смеси золотосульфидного и свинцово-цинкового концентратов оптимально их соотношение 1:1. Выход кека составляет $50 \%$, извлечение серы и мышьяка в раствор 73 и $42 \%$ соответственно, а продолжительность АО - 50 мин.

Показано, что при совместной плавке свинцовых и золотосодержащих концентратов содержание свинца в черновом металле составляет 87-93 \%, основной примесью является сурьма. Извлечение свинца и драгоценных металлов в черновой свинец составило 96-98 и 98-99 \% соответственно.

Полупромышленные испытания автоклавно-пирометаллургической технологии на смесях золотосульфидных концентратов Удерейского, Боголюбовского и Олимпиадинского месторождений со свинцово-цинковым флотоконцентратом месторождения «Горевское» подтвердили результаты лабораторных исследований.

По результатам исследований и полупромышленных испытаний разработана комбинированная автоклавно-пирометаллургическая технология для совместной переработки золотосульфидных и свинцово-цинковых концентратов, позволяющая извлекать 97 \% драгоценных металлов и 95 \% цинка и свинца в товарные продукты. Данная технология дает возможность отказаться от цианирования кеков автоклавного окисления.

\section{Список литературы}

1. Лодейщиков В.В. Технология извлечения золота и серебра из упорных руд. Иркутск: ОАО «Иргиредмет», 1999. 786 c [Lodeischikov V.V. The technology of gold and silver recovery from refractory ores. Irkutsk: Irgiredmet JSC, 1999. 786 p. (in Russian)]

2. Баликов С.В., Дементьев В.Е., Минеев Г.Г. Обжиг золотосодержащих концентратов. Иркутск: ОАО «Иргиредмет», 2002. 416 с [Balikov S.V., Dementev V.Ye., Mineev G.G. Roasting of gold-bearing concentrates. Irkutsk: IRGIREDMET JSC, 2002. 416 p. (in Russian)]

3. Котляр Ю.А., Меретуков М.А. Металлургия благородных металлов. М.: АСМИ, 2002. 465 c. [Kotliar Yu.A., Meretukov M.A. Metallurgy of precious metals. Moscow, 2002. 465 p. (in Russian)]

4. Hourn M., Rohner P., Bartsch P., Ngoviky K. Benefits of Using The Albion Process for a North Queensland Project, and a Case Study of Capital and Operating Cost Benefits Versus Bacterial Oxidation and Pressure Oxidation, Randol Innovative Metallurgy Forum 2005. Perth. Australia; http:// 
www.albionprocess.com/EN/downloads/TechnicalPapers/Benefits \%20of \%20Using \%20the \%20 Albion \%20Process \%20for \%20a \%20North \%20Queensland \%20Project \%20- \%20Randoll \%20 $2006 \% 20(3)$.pdf

5. Adams M.D. Advances in gold ore processing. 2005. Chapter 15 (Thomas K.G. Pressure oxidation overview). P. 346-369.

6. Епифоров А.В., Богородский А.В., Баликов С.В., Емельянов Ю.Е., Копылова Н.В. Автоклавное окисление упорного сульфидного медно-мышьякового золотосодержащего флотоконцентрата. Материаль международного совещания (Плаксинские чтения-2011). Екатеринбург, 2011. C. $561-562$ [Epiforov A.V., Bogorodsky A.V., Balikov S.V., Emelianov Yu.E., Kopylova N.V. Pressure oxidation of refractory copper-arsenic sulfide gold-bearing flotation concentrate. Materialy mezhdunarodnogo soveshchaniya "Plaksinskiye Chtenya-2011" (Materials of international meeting "Plaksin readings - 2011"). Ekaterinburg, 2011. P. 561-562 (in Russian)]

7. Епифоров А.В., Богородский А.В., Баликов С.В., Емельянов Ю.Е., Копылова Н.В. Лабораторные исследования высокотемпературного автоклавного окисления полиметаллических золотосодержащих сульфидных концентратов. Вестник ИрГТУ 2012. Т. 1(60). С. 116-119. [Epiforov A.V., Bogorodsky A.V., Balikov S.V., Emelianov Yu.E., Kopylova N.V. Laboratory studies of high-temperature autoclave oxidation of polymetallic goldbearing sulfide concentrates. Vestnik of Irkutsk State Technical Universty 2012. Vol. 1(60). P. 116-119 (in Russian)]

8. Воробьев-Десятовский Н.В., Епифанов А.В. Автоклавное окисление дважды упорных золотосодержащих руд. Проблемы и пути решения. (10 Горнопромышленный форум «Минерально-сырьевой комплекс России - новые рубежи и вызовы». МАЙНЕКС Россия 2014) [Vorobiev-Desyatovsky N.V., Yepifanov A.V. Pressure oxidation of double refractory gold-bearing ores. Problems and the ways of solving. The materials of $10^{\text {th }}$ mining industry forum "Mineral resources sector of Russia: new frontiers and challenges" (Minex Russia 2014), Moscow (in Russian)]

9. Patent 03060172 A2 (US). High Temperature Pressure Oxidation of Ore and Ore Concentrates Containing Silver Using Controlled Precipitation of Sulfate Species. Simmons G.L., Gathje J.C, 2003.

10. Набиулин Р.Н., Дзгоев Ч.Т., Епифоров А.В., Емельянов Ю.Е. Сопоставление способов окислительного выщелачивания свинцово-цинкового флотоконцентрата. Материалы международного совещания (Плаксинские чтения-2015), Иркутск, 2015, 368-370 [Nabiulin R.N., Dzgoev Ch.T., Epiforov A.V., Emelianov Yu.E. Comparison of the oxidative leaching of lead and zinc flotation concentrate. Materialy mezhdunarodnogo soveshchaniya "Plaksinskye Chtenya-2015" (Materials of international meeting "Plaksin readings - 2015”), Irkutsk, 2015, 368-370 (in Russian)]

11. Епифоров А.В., Дзгоев Ч.Т., Емельянов Ю.Е., Евтушевич И.И., Болдырев А.В. Полупромышленные испытания технологии автоклавного окисления золотосодержащего сырья сложного минерального состава. Вестник ИрГТУ 2015, Т. 6(101). C. 147-151 [Epiforov A.V., Dzgoev Ch.T., Emelianov Yu.E., Evtushevich I.I., Boldyrev A.V. Pox pilot plant testing of complex gold-bearing mineral raw materials. Vestnik of Irkutsk State Technical Universty 2015. Vol. 6(101). P. 147-151 (in Russian)]

12. Набиулин Р.Н., Епифоров А.В., Минеева Т.С. Влияние крупности материала на процесс автоклавного окисления сульфидов. Перспективы развития технологии переработки углеводородных и минеральных ресурсов: мат-лы V Всерос. науч.-практ. конф. с междунар. участием 2015. C. 34-36. [Nabiulin R.N., Dzgoev Ch.T., Epiforov A.V., Emelianov Yu.E. Effect of Particle 
Size on the process of autoclave oxidation of sulfides. Prospects for the development of technologies for processing of hydrocarbon and mineral resources: $V$ Vseros. nauch.-prakt. konf. s mezhdunar. uchastiyem 2015. P. 34-36 (in Russian)]

13. Fleming C. A. Basic iron sulphate - a potential killer for pressure oxidation processing of refractory gold concentrates if not handled appropriately. SGS Minerals services 2009, 6; http:// www.sgsgroup.it/ /media/Global/Documents/Technical \%20Documents/SGS \%20Technical \%20 Papers/SGS \%20MIN \%20TP2009 \%2006 \%20Basic \%20Iron \%20Sulphate \%20in \%20POX \%20 Processing \%20of \%20Refractory \%20Gold.pdf

14. Дзгоев Ч.Т., Евтушевич И.И., Штойк С.Г., Епифоров А.В., Гудков С.С., Емельянов Ю.Е. Автоклавно-пирометаллургическая технология переработки сульфидных золотосодержащих и свинцово-цинковых флотоконцентратов. Материалы международного совещания (Плаксинские чтения-2015). Иркутск, 2015. С. 338-340 [Dzgoev Ch.T., Evtushevich I.I., Shtoik S.G., Epiforov A.V., Gudkov S.S., Emelianov Y.Ye. Autoclave-pyrometallurgical technology for processing sulfide gold-bearing and lead-zinc flotation concentrates. Materialy mezhdunarodnogo soveshchaniya "Plaksinskye Chtenya-2015” (Materials of international meeting “Plaksin readings - 2015”). Irkutsk, 2015. P. 338-340 (in Russian)]

15. Евтушевич И.И., Дзгоев Ч.Т., Епифоров А.В., Емельянов Ю.Е. Автоклавный метод совместной переработки сульфидных золотосодержащих и свинцовых концентратов. Цветные металль 2016, Т. 6. C. 51-55 [Evtushevich I.I., Dzgoev Ch.T., Epiforov A.V., Emelianov Y.Ye. Autoclave method of joint processing of sulfide gold-bearing and lead concentrates. Tsvetnye Metally = Non-ferrous metal 2016. Vol. 6. P. 51-55 (in Russian)]

16. Dzgoev Ch.T., Evtushevich I.I., Shtoik S.G., Gudkov S.S., Epiforov A.V., Emelianov Y.Ye., Balikov S.V. Pressure oxidation pyrometallurgical technology of gold-bearing and lead and zinc sulfide concentrates combined treatment. Proceedings of XXVIII International Mineral Processing Congress (IMPC 2016). Québec city, Canada, 2016, 801.

17. Решение о выдаче евразийского патента № 201500121/28 Способ извлечения драгоценных металлов из упорного сульфидного сырья / В.В. Гуриев, И.И. Евтушевич, Ч.Т. Дзгоев, С.Г. Штойк, С.С. Гудков, А.В. Епифоров, Ю.Е. Емельянов, В.Е. Дементьев, С.В. Баликов. Заявл. 22.01.2015. Решение о выдаче от 27.10. [The decision to grant a Eurasian patent № 201500121/28. A method to recover precious metals from refractory sulfide materials. V.V. Guriev, I.I. Evtushevich, Ch.T. Dzgoev, S.G. Shtoik, S.S. Gudkov, A.V. Epiforov, Y.Ye. Emelianov, V.E. Dement'yev, S.V. Balikov, 2016 (in Russian)] 